\title{
How does the grade obtained at school for English and Mathematics affect the probability of graduation at a university?
}

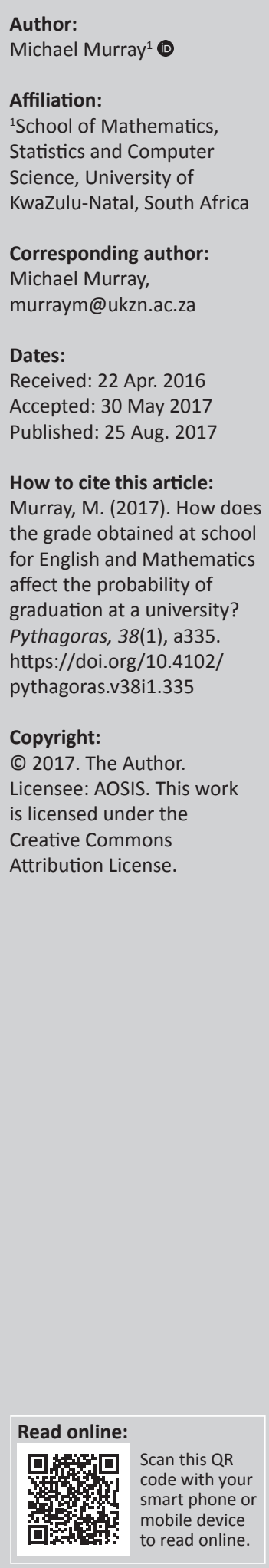

Over half of all students enrolling at a particular university in KwaZulu-Natal fail to complete a degree. This article aims to determine to what extent the marks they obtain for English and Mathematics at school impact on their probability of graduation at this university. In addressing this problem, other student specific factors associated with their gender, race and the type of school they attended need also to be properly accounted for. To provide answers for this study, the performance of 24392 students enrolling at the university over the period 2004 to 2012 was followed until they graduated or dropped out from their studies. A structural equation model was fitted because it allows one to separate a direct effect from that of an indirect effect. Gender, race and school background were found to be very significant with men, Black Africans and students coming from a less privileged school background having a smaller probability associated with eventually graduating from this university. Men tend to perform better than women in Mathematics, with women performing better men in English. More importantly, however, a single percentage point increase in one's mark for English increases the probability associated with graduating from this university far more than would be the case if their Mathematics mark were to increase by a single percentage point. In light of these mediated results, perhaps this university should be directing their efforts more towards improving the English (rather than mathematical) literacy of students entering the university.

\section{Introduction}

Prior to 2008 students completing their school-leaving Grade 12 examinations in South Africa could take subjects at a higher or a standard grade level. In 2008 all subjects were collapsed into a single grade with Mathematical Literacy being offered as an alternative for students who would have preferred to take Mathematics at a standard grade level prior to 2008. Entry into a particular programme at a specific university in KwaZulu-Natal in South Africa (hereafter the university) depends on an appropriate level of marks (called a matric point score) being recorded for these school-leaving examinations. This article seeks to determine to what extent the marks that are being recorded for English and Mathematics impact on students' probability of graduation at this university. Factors associated specifically with the student such as their gender, race and age and the type of school they attended may also have an impact on the probability associated with graduation from the university. Factors that are specific to the university such as their college of enrolment and whether they have been given residence-based accommodation need also to be controlled for when attempting to produce an appropriate model for predicting graduation at the university. By making use of a structural equation based methodology, this article allows each one of the above factors to have a direct effect on the probability associated with graduation; some of these factors (namely race, gender and type of school) also exert an indirect effect on graduation that is being mediated by the marks that students are managing to obtain in English and Mathematics for their school-leaving examinations.

\section{Literature review}

Support for some of the factors that we will be including in our structural equation based prediction model come from a variety of international and locally based studies. Naylor and Smith (2005) found that gender and school type play a very significant role in determining how students perform at a UK university. Tomul and Savasci (2012) found that school type was a very strong predictor for determining academic success at a university. Surprisingly, family background variables such as parents' educational status, income and fathers' occupation were found not to be very strong predictors in their particular study. Caldas and Bankston (2004) also obtained similar results, noting that the type of dwelling in which the family lives and the number of siblings in the 
family were also not very strong predictors of student achievement. Chiu (2007), in an extensive study covering 41 countries, found that students who lived with two parents, lived without grandparents and lived with fewer siblings (especially older ones) did better in their studies. In a United Kingdom based study, Thiele, Singleton, Pope and Stanistreet (2016) found that living in a more deprived area adversely affected student performance. Race was also found to be an important factor with Asian and Black students not performing as well as White students. They also found that female students performed better than male ones in the more language-based disciplines, a result which will also be borne out in our study. In the United States, Coleman et al. (1996) found that the type of school being attended did not always have a significant effect on the academic success of a student at a university. Instead, they found that academic performance was being determined primarily by the living conditions that exist in one's home and the relationships that one has with one's family. In South Africa, however, apartheid has created a dysfunctional society with people from similar racial and socioeconomic backgrounds being forced to live together in townships and rural settlements that are often very poorly resourced. Many of these homes will have absentee fathers who are being forced to seek employment far away from their family's place of residence.

Wealthier schools will be able to appoint better qualified teachers. Added to this mix is a powerful teacher's union whose policies attempt to entrench the job security of teachers in the less wealthy schools irrespective of whether they can teach their subjects or not. In a recent study, Murray (2016) found this to be an important factor affecting performance at the university. Consequently, effects that have been observed in other international studies may not be true given a South African context.

Bohlmann and Pretorius (2008) found that the marks that South African students obtain for important school subjects such as Mathematics and English do not necessarily serve as very strong predictors for determining whether a student will be able to succeed in their studies at a university level. Spaull (2011) and Van der Berg (2008) found that South African learners coming from a poor socioeconomic background, when given the opportunity to attend a better resourced school, are often able to significantly improve their mathematical and reading skills. Complicating matters, however, is the fact that teaching in most of these township schools is being done in one's mother tongue with a switchover to English only taking place later on in one's primary school education. Because students entering their high school years, are now being taught important concepts in another language, the lack of meaning that they are now experiencing with the texts that they are having to read is being 'overcome' with a culture of rote learning. Bird and Welford (1995) have highlighted this problem in South Africa, suggesting that this culture of rote learning is one of the main causes for the high failure rates that are being recorded at most of the universities in South Africa.
Studies by Feast (2002), Howie (2003), Van Dyk, Zybrands, Cillie and Coetzee (2009) and Johnstone and Selepeng (2001) have also all found, at both a tertiary and higher education level, that differences between an institution's language of teaching and a student's home language negatively affect a student's ability to successfully complete a course or degree. By allowing race, gender and school background to impact directly on the probability being associated with graduation at this university, and then also to impact indirectly on this probability through a mechanism that is being mediated by the marks obtained in English and Mathematics schoolleaving examinations, questions along the following lines can now hopefully be appropriately answered:

- Do women perform better than men at university?

- Do women perform better than men even after an appropriate adjustment has been made for other predictive factors associated with race, school background, college of enrolment and the receipt of residence-based accommodation?

- How do women who have done well in English at school compare with those who have not done well in English with respect to their performance at university?

\section{Research methodology}

The data that have been used for this study comes from a university situated in KwaZulu-Natal. A total of 24392 students enrolled for a degree at this university over the period 2004 to 2012. For each student, the mark (expressed as a percentage) that they obtained for Mathematics and English in their school-leaving examinations was collected together with some of the other more important predictor variables that have been highlighted in the previous section of this article. University specific variables indicating whether or not they received some form of residence-based accommodation while studying at university were also included together with the college in which they chose to study. Table 1 contains a listing of all the predictor variables that were collected. National Senior Certificate refers to a new single grade-based exam that was introduced in 2008 to replace the standard and higher grade examinations that were in existence before that

\begin{tabular}{|c|c|}
\hline Variable name & Definition \\
\hline Male & $\begin{array}{l}1=\text { male student } \\
0=\text { female student }\end{array}$ \\
\hline $\begin{array}{l}\text { National Senior } \\
\text { Certificate }\end{array}$ & $\begin{array}{l}1=\text { wrote the National Senior Certificate examination } \\
0=\text { did not write the National Senior Certificate examination } \\
\text { (pre-2008 qualification) }\end{array}$ \\
\hline Residence & $\begin{array}{l}1=\text { given residence-based accommodation } \\
0=\text { did not receive residence-based accommodation }\end{array}$ \\
\hline Black African & $\begin{array}{l}1=\text { Black African student } \\
0=\text { from another race group }\end{array}$ \\
\hline $\begin{array}{l}\text { Agriculture, } \\
\text { Engineering \& } \\
\text { Science }\end{array}$ & $\begin{array}{l}1=\text { student enrolled in College of Agriculture, Engineering \& } \\
\text { Science } \\
0=\text { from another College }\end{array}$ \\
\hline $\begin{array}{l}\text { Law \& } \\
\text { Management }\end{array}$ & $\begin{array}{l}1=\text { student enrolled in College of Law \& Management } \\
0=\text { from another college }\end{array}$ \\
\hline Health Sciences & $\begin{array}{l}1=\text { student enrolled in College of Health Sciences } \\
0=\text { from another college }\end{array}$ \\
\hline Humanities & $\begin{array}{l}1=\text { student enrolled in College of Humanities } \\
0=\text { from other college }\end{array}$ \\
\hline Quintile 5 & $\begin{array}{l}1=\text { student went to a quintile } 5 \text { school } \\
0=\text { did not go to a quintile } 5 \text { school }\end{array}$ \\
\hline
\end{tabular}


date. Permission to use this data set was given by the Teaching and Learning Office at the university.

The results in Table 2 indicate that students enrolling for a degree at this university are performed better in English than Mathematics when writing their school-leaving examinations. Because a national body adjusts the marks that are obtained for each subject according to a set of targeted guidelines, one cannot interpret this result as necessarily implying that Mathematics is a more difficult subject to take than English at a matric level. Nor can it be argued that the knowledge base that they will need to succeed with their studies at this university is better for English because the average marks being recorded for English are higher than those being recorded for Mathematics.

\section{School quintile}

All public schools in South Africa are given a ranking based on the level of poverty that exists within the community in which the school is located. This ranking takes into account the average level of income that is earned by someone in the area surrounding that school, the unemployment rate and the level of education within that community. Schools falling in the bottom $20 \%$ of this ranking (i.e. the poorest schools) are then classified as being quintile 1 schools. Schools falling within the top $20 \%$ of this ranking are said to be quintile 5 schools. In Table 3, t-tests comparing the performance of students in English and Mathematics at a quintile 5 school with those coming from a less privileged quintile 1-4 school indicate unsurprisingly that students in the better resourced quintile 5 schools perform significantly better than students coming from the less privileged quintile 1-4 schools. This result may be a reflection of better teaching of these subjects at the quintile 5 schools. It could also reflect a greater level of 'spoon-feeding' and rote learning, which may not necessarily translate into a higher probability of being able to graduate at a university when faced with the extra workload pressures that exist in a university environment. Interestingly enough, the results in Table 3 suggest that the gap in performance between the quintile 5 and quintile 1-4 schools is much greater in English than Mathematics. A greater prevalence of mother tongue based instruction in the poorer quintile 1-4

TABLE 2: Performance measures for English and Mathematics over the period 2004-2012.

\begin{tabular}{llcc}
\hline Subject & Definition & Mean (\%) & Standard deviation \\
\hline English & $\begin{array}{l}\text { Percentage mark obtained for } \\
\text { English in the school-leaving } \\
\text { examination }\end{array}$ & 69.51 & 10.21 \\
Mathematics & $\begin{array}{l}\text { Percentage mark obtained } \\
\text { for Mathematics in the } \\
\text { school-leaving examination }\end{array}$ & 64.06 & 17.49 \\
\hline
\end{tabular}

schools may be a reason for this. Also, the teaching of Mathematics lends itself more easily to the application of a 'correct' formula without a basic understanding of why this formula is necessary. Consequently, extra marks can be more easily obtained in Mathematics than would be the case when having to write for example an English essay.

\section{Choice of response variable}

A $0 / 1$ variable indicating whether a student has eventually been able to graduate from this university has been used as a response variable $\mathrm{Y}$ for this article. Students who were still busy with their studies when the study period ended were deleted from the data set. The results given in Table 4 indicate that more than half of the students who enroll for a degree at this university fail to complete their degree. We want to determine what sort of effect the variables listed in Table 1 have on a student's prospect of eventually graduating. Given that each one of these students would have taken Mathematics and English as a subject at school, by allowing the effect of race, gender and school background (on graduation) to be mediated through the type of mark they recorded for Mathematics and English, we also want to determine whether the university should be looking at offering an extra course in English or Mathematics (or both) to help students bridge the gap that exists between what they actually know and what they need to know in order to improve their chances of graduating at this university.

\section{Results}

\section{A logistic regression based analysis}

Table 5 contains graduation rates for each one of the variables listed in Table 1. Focusing on gender one can see that women have more chance of graduating with a degree from this university. Black Africans do not perform as well as nonBlack Africans, students coming from a quintile 5 background do better than students coming from a less privileged school background. Students enrolled in the College of Agriculture, Engineering and Science do not do as well as students enrolled in one of the other colleges.

All the results given in Table 5 however represent marginal effects. Fitting a logistic model to all the covariates that appear in this table will allow each effect to be estimated after an appropriate adjustment for all the other variable effects have been made. An interaction term denoting whether as a

TABLE 4: Observed graduation rates at the university over the period 2004-2012.

\begin{tabular}{lc}
\hline Outcome & Frequency (\%) \\
\hline Did not graduate & 56.73 \\
Did graduate & 43.27 \\
\hline
\end{tabular}

TABLE 3: Two sample test results for comparing the Mathematics and English results of quintile 5 schools with quintile 1-4 schools (assuming unequal variances in the grouped populations).

\begin{tabular}{|c|c|c|c|c|c|}
\hline Subject & Population groups & Number of observations & Mean & Standard error & Two sample $t$-test for unequal means \\
\hline English & $\begin{array}{l}\text { Quintile } 5 \text { school } \\
\text { Quintile 1-4 school }\end{array}$ & $\begin{array}{r}14957 \\
9435\end{array}$ & $\begin{array}{l}71.66 \\
66.10\end{array}$ & $\begin{array}{l}0.19 \\
0.19\end{array}$ & $41.32 *$ \\
\hline Mathematics & $\begin{array}{l}\text { Quintile } 5 \text { school } \\
\text { Quintile 1-4 school }\end{array}$ & $\begin{array}{r}14957 \\
9435\end{array}$ & $\begin{array}{l}64.98 \\
62.59\end{array}$ & $\begin{array}{l}0.13 \\
0.19\end{array}$ & $10.19 *$ \\
\hline
\end{tabular}

*, denotes significance at $5 \%$ level. 
Black African child they attended a quintile 5 school has also been included in the results that appear in Table 6 .

Parameter estimates that are significantly positive in value indicate covariates that will help to increase the probability associated with graduating from the university. For example, the parameter estimate -0.237 associated with being male implies that men have a smaller probability associated with eventually graduating than women. In terms of an odds ratio, the above estimate implies that the probability associated with a man graduating is 0.789 times the probability associated with a woman graduating; i.e. $\frac{P(\text { male student graduates })}{P(\text { female student graduates })}=e^{-0.237}=0.789$.

Using a 5\% level of significance, the results in Table 6 suggest that male and Black African students have significantly less chance of graduating than female and non-Black students. Those who wrote the National Senior Certificate did not performing as well as those who finished matric before 2008 . Obtaining a higher mark for Mathematics and English can be associated with an increased probability of eventually graduating. Focusing on college of enrolment it is important to note that students in the College of Management Studies and Law form a baseline college from which to make a

\begin{tabular}{llcc} 
TABLE 5: A demographic breakdown of graduation rates at this university. \\
\hline Covariate & Outcome & $\begin{array}{c}\text { Proportion of students } \\
\text { being represented } \\
\text { in the sample }\end{array}$ & $\begin{array}{c}\text { Percentage } \\
\text { who } \\
\text { graduated }\end{array}$ \\
\hline Male & Yes & 0.423 & 0.384 \\
Black African & No & 0.577 & 0.439 \\
& No & 0.425 & 0.341 \\
Quintile 5 & Yes & 0.575 & 0.501 \\
& No & 0.613 & 0.454 \\
National Senior & Yes & 0.387 & 0.334 \\
Certificate & No & 0.404 & 0.231 \\
Residence & Yes & 0.596 & 0.687 \\
& No & 0.273 & 0.427 \\
College & Agriculture, Engineering & 0.727 & 0.383 \\
& and Science & 0.282 & 0.345 \\
& Humanities & & 0.471 \\
& Health Sciences & 0.077 & 0.425 \\
& Law and Management & 0.366 & 0.459 \\
\hline
\end{tabular}

comparison. Thus, students enrolled in the College of Humanities or the College of Health Sciences have a higher probability associated with graduating when compared with a student enrolldc in the College of Management Studies and Law. Students in the College of Agriculture, Engineering and Science have a smaller probability associated with graduating when compared with a student enrolldc in the College of Management Studies and Law.

\section{A structural equation model based analysis}

In this section, we will focus on the marks that students obtained for Mathematics and English when writing their school-leaving examinations. Given that these subjects are compulsory for all school leavers we want to identify whether obtaining a particular mark for Mathematics improves one's probability of graduating from this university more than obtaining the same mark for English. At the same time, we want to separate the total effect that race, gender and school background have on graduation into an indirect effect that is mediated by the type of mark obtained at school for Mathematics and English and a direct effect representing the residual effect of these three factors on graduation that results after having controlled for the mediation effects of Mathematics and English. By doing this, we can now address other issues that may be of interest such as whether the university should look at offering an extra course in English or Mathematics (or both) to help students bridge the gap between what they actually know and what they need to know in order to improve their chances of graduating at this university.

Structural equation based models allow one to estimate direct and indirect effects for a given problem. Referring to the diagram given in Figure 1, the observed variables are represented by rectangular boxes with an arrow between boxes representing a hypothesised pathway between these variables whose 'value' we want to estimate. The arrow linking the box labelled Black African, Male and Quintile 5 school to the box labelled Graduated represents a set of direct path-based effects for race, gender and school background that we want to estimate. The arrows linking the box labelled Black African, Male and Quintile 5 school to the box labelled Graduated via a pathway that passes through

TABLE 6: Parameter estimates associated with covariates affecting the probability of graduation at the university.

\begin{tabular}{|c|c|c|c|c|}
\hline Covariates & Parameter estimate & Standard error & [95\% confidence interval] & Odds ratio \\
\hline English & 0.021* & 0.002 & {$[0.017 ; 0.024]$} & 1.021 \\
\hline Mathematics & $0.009 *$ & 0.001 & {$[0.007 ; 0.011]$} & 1.009 \\
\hline Quintile 5 & $0.111^{*}$ & 0.047 & {$[0.017 ; 0.205]$} & 1.117 \\
\hline Quintile $5 \times$ Black African & 0.097 & 0.067 & {$[-0.034 ; 0.229]$} & 1.102 \\
\hline Male & $-0.237 *$ & 0.031 & {$[-0.297 ;-0.177]$} & 0.789 \\
\hline Black African & $-0.427^{*}$ & 0.059 & {$[-0.543 ;-0.312]$} & 0.652 \\
\hline Residence & $0260 *$ & 0.048 & {$[0.165 ; 0.355]$} & 1.297 \\
\hline Agriculture, Engineering and Science & $-0.637^{*}$ & 0.037 & {$[-0.711 ;-0.565]$} & 0.529 \\
\hline Humanities & $0.078^{*}$ & 0.038 & {$\left[\begin{array}{lll}0.003 & 0.154\end{array}\right]$} & 1.081 \\
\hline Health & 0.624 & 0.075 & {$[0.477 ; 0.771]$} & 1.866 \\
\hline National Senior Certificate & $-1.144 *$ & 0.030 & {$[-1.203 ;-1.085]$} & 0.319 \\
\hline Constant & $-0.797 *$ & 0.142 & {$[-1.075 ;-0.519]$} & - \\
\hline
\end{tabular}

*, denotes significance at $5 \%$ level. 
the box labelled Mathematics and English represents a set of indirect effects associated with race, gender and school background whose estimated effects on graduation we also want to estimate. Estimation of these path-based coefficients is done using a maximum likelihood method with the fit of the model structure being based on a comparison of the observed variance covariance matrix and the variance covariance matrix that is implied by the path model in Figure 1.

Path-based estimates associated with the fitting of a logistic model to that part of the path model in Figure 1 that affects graduation are given in Table 7 . Odds ratios have been included to help with the interpretation of direct effects, noting that these are effects that are observed after an appropriate adjustment for the effects of other variables in the table have been made. Path-based estimates for the indirect effects that are mediated through Mathematics and English are given in Table 8.

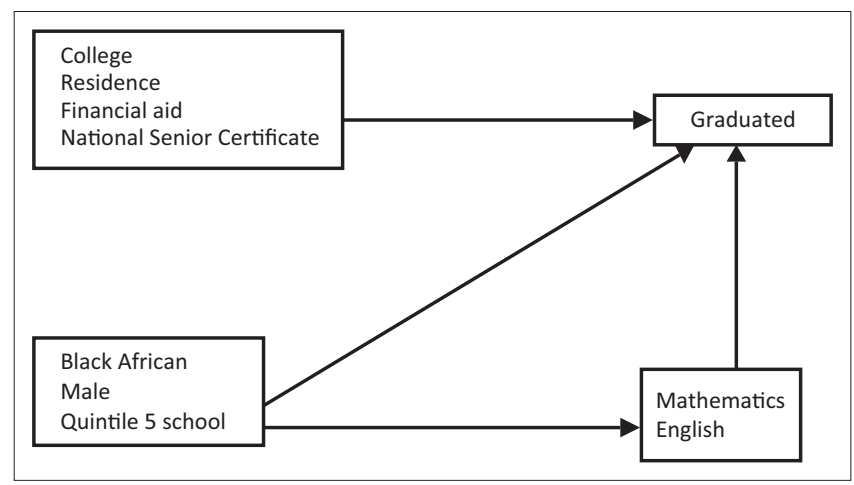

FIGURE 1: A structural equation model for graduation with direct and indirect mediated effects.
Focusing on the direct effect estimates that are given in Table 7, noting that these estimates include an appropriate adjustment for the mediation effects of English and Mathematics that form part of Table 8, coming from a more privileged school background increases the probability of graduating at this university. Male and Black African students have a smaller probability of graduating and staying in residence improves one's probability of graduating from this university. At a college level, students enrolled in the College of Agriculture, Engineering and Science have less chance of graduating than students enrolled in the College of Law and Management Studies. Students enrolled in the College of Humanities or the College of Health Sciences however have more chance of graduating than students enrolled in the College of Law and Management Studies. The strongest direct effect of all on graduation is the effect recorded by students who wrote the National Senior Certificate examinations. These students significantly underperformed when compared with someone who wrote the higher and lower grade examinations that were in existence before 2008 .

Focusing on the path-based estimates that appear in Table 8 linking English and Mathematics to the probability of graduation, not unsurprisingly having a higher mark for either subject improves one's probability of eventually graduating from this university. Consequently, offering appropriate bridging courses in English or Mathematics for students enrolling at this university should help to improve graduation rates at this institution. More importantly, however, the estimated effect for English (0.021) is more than double that for Mathematics (0.009) implying that a single

TABLE 7: Direct effect estimates associated with graduation for the model structure given in Figure 1.

\begin{tabular}{|c|c|c|c|c|}
\hline Path & Parameter estimate & Standard error & [95\% Confidence interval] & Odds ratio \\
\hline Quintile $5 \rightarrow$ Graduate & $0.113^{*}$ & 0.047 & {$[0.017 ; 0.204]$} & 1.119 \\
\hline Quintile $5 \times$ Black African $\rightarrow$ Graduate & 0.097 & 0.067 & {$[-0.034 ; 0.229]$} & 1.101 \\
\hline Male $\rightarrow$ Graduate & $-0.237 *$ & 0.031 & {$[-0.297 ;-0.178]$} & 0.789 \\
\hline Black African $\rightarrow$ Graduate & $-0.427 *$ & 0.059 & {$[-0.543 ;-0.312]$} & 0.652 \\
\hline Residence $\rightarrow$ Graduate & $0.260 *$ & 0.048 & {$[0.165 ; 0.355]$} & 1.297 \\
\hline Agriculture, Engineering and Science $\rightarrow$ Graduate & $-0.637^{*}$ & 0.037 & {$[-0.710 ;-0.564]$} & 0.529 \\
\hline Humanities $\rightarrow$ Graduate & $0.078 *$ & 0.039 & {$[0.002 ; 0.153]$} & 1.081 \\
\hline Health Sciences $\rightarrow$ Graduate & $0.624 *$ & 0.075 & {$[0.477 ; 0.770]$} & 1.866 \\
\hline National Senior Certificate $\rightarrow$ Graduate & $-1.144^{*}$ & 0.030 & {$[-1.203 ;-1.085]$} & 0.318 \\
\hline Constant $\rightarrow$ Graduate & $-0.797 *$ & 0.142 & {$[-1.075 ;-0.519]$} & - \\
\hline
\end{tabular}

*, denotes significance at $5 \%$ level.

TABLE 8: Indirect effect estimates that are mediated through Mathematics and English.

\begin{tabular}{|c|c|c|c|c|}
\hline Path & Parameter estimate & Standard error & [95\% confidence interval] & Odds ratio \\
\hline Black African $\rightarrow$ English & $-10.016 *$ & 0.197 & {$[-10.404 ;-9.629]$} & - \\
\hline Quintile $5 \rightarrow$ English & $0.466 *$ & 0.186 & {$[0.101 ; 0.830]$} & - \\
\hline Quintile $5 \times$ Black African $\rightarrow$ English & $1.546^{*}$ & 0.255 & {$[1.045 ; 2.046]$} & - \\
\hline Male $\rightarrow$ English & $-3.440 *$ & 0.113 & {$[-3.663 ;-3.216]$} & - \\
\hline Constant $\rightarrow$ English & $74.283^{*}$ & 0.172 & {$[73.945 ; 74.621]$} & - \\
\hline Male $\rightarrow$ Mathematics & $3.720^{*}$ & 0.219 & {$[3.291 ; 4.149]$} & - \\
\hline Quintile $5 \rightarrow$ Mathematics & -0.510 & 0.359 & {$[-1.214 ; 0.194]$} & - \\
\hline Quintile $5 \times$ Black African $\rightarrow$ Mathematics & 0.437 & 0.498 & {$[-0.539 ; 1.413]$} & - \\
\hline Constant $\rightarrow$ Mathematics & $65.716^{*}$ & 0.332 & {$[65.066 ; 66.368]$} & - \\
\hline English $\rightarrow$ Graduate & $0.021^{*}$ & 0.002 & {$[0.017 ; 0.024]$} & 1.021 \\
\hline Mathematics $\rightarrow$ Graduate & $0.009 *$ & 0.001 & {$[0.007 ; 0.011]$} & 1.009 \\
\hline
\end{tabular}

*, denotes significance at $5 \%$ level. 
percentage increase in one's mark for English increases the probability of graduating much more than a single percentage increase in one's mark for Mathematics. In light of these mediated results, should a choice between running a bridging course in Mathematics or a course in English be necessary, more attention and resources should be directed towards improving the English (rather than mathematical) literacy of students entering this institution.

\section{Gender}

Focusing on gender and its mediated effect on graduation based on the type of mark recorded for Mathematics and English, the results given in Table 9 indicate clearly that men tend to do better than women in Mathematics with the opposite being true for English. The path-based estimates that appear in Table 8 linking Male to English and Mathematics respectively reinforce this fact. In particular, after an appropriate adjustment for race and school background has been made, men score a mark for Mathematics that is on average $3.7 \%$ higher than that for women. Women, on the other hand, do better in the languages, scoring a mark for English that is on average 3.4\% higher than that for men. With these results in hand, the university may want to 'consider' introducing a bridging course in Mathematics for women and a bridging course in English for men enrolling at this university.

\section{Race}

Focusing on race and its mediated effect on graduation based on the type of mark recorded for Mathematics and English, the results given in Table 10 indicate for both subjects that Black African students significantly underperform when being compared with non-Black African students. The pathbased estimates in Table 8 linking Black African to English and Mathematics reinforce this fact.

\section{School background}

Focusing on school background, the inclusion of an interaction term (Quintile $5 \times$ Black African) that denotes a

TABLE 9: Two sample test results comparing the Mathematics and English results of men with women (assuming unequal variances in the grouped populations).

\begin{tabular}{llcccc}
\hline Subject & Gender & $\begin{array}{c}\text { Number of } \\
\text { observations }\end{array}$ & Mean & $\begin{array}{c}\text { Standard } \\
\text { error }\end{array}$ & $\begin{array}{c}\text { Two sample } \boldsymbol{t} \text {-test } \\
\text { for unequal means }\end{array}$ \\
\hline Mathematics & Male & 10341 & 66.04 & 0.17 & $15.26^{*}$ \\
& Female & 14051 & 62.60 & 0.15 & \\
English & Male & 10341 & 67.08 & 0.10 & $-32.23^{*}$ \\
& Female & 14051 & 71.29 & 0.08 & \\
\hline
\end{tabular}

*, denotes significant at $5 \%$ level.

TABLE 10: Two sample test results comparing the Mathematics and English results of Black African with non-Black African students (assuming unequal variances in the grouped populations).

\begin{tabular}{llcccc}
\hline Subject & Race & $\begin{array}{c}\text { Number of } \\
\text { observations }\end{array}$ & Mean & $\begin{array}{c}\text { Standard } \\
\text { error }\end{array}$ & $\begin{array}{c}\text { Two sample } \\
\text { t-test for } \\
\text { unequal means }\end{array}$ \\
\hline Mathematics & Black African & 10373 & 60.26 & 0.17 & $-29.36^{*}$ \\
& Non-Black African & 14019 & 66.87 & 0.14 & \\
English & Black African & 10373 & 64.09 & 0.09 & $-78.47^{*}$ \\
& Non-Black African & 14019 & 73.52 & 0.07 & \\
\hline
\end{tabular}

*, denotes significant at $5 \%$ level.
Black African who attended a quintile 5 school allows one to isolate the direct and mediated effect on graduation of this cohort from that of other non-Black African students who also attended a more privileged quintile 5 school. The results in Table 7 indicate that attending a quintile 5 school increases the probability of being able to graduate at this university.

\section{Conclusions}

In this article, we have been concerned primarily with constructing an appropriate prediction model for graduation at the university. By making use of a structural equation model we have been able to model not only the direct effects associated with graduation but also the indirect effects that have been appropriately mediated by the marks that students obtain for English and Mathematics in their schoolleaving examinations. Focusing on the direct effects that were observed, gender and race play a significant role with men having a smaller probability of graduating (when compared to women) and Black African students not doing as well as their non-Black African counterparts. Students coming from a more privileged school background have a greater probability of eventually graduating from the university.

Focusing on the indirect effects, a strong gender bias emerges with men tending to perform better in Mathematics than women and women better than men in English. More importantly, however, a single percentage increase in one's mark for English serves to increase the probability of graduating from the university by an amount which far exceeds what would be the case with a single percentage point increase in one's Mathematics mark.

In light of these mediated results, when it comes to holding a discussion around bridging and the type of courses that should be developed for struggling students, more attention should be given towards improving the English (rather than mathematical) literacy of students entering this institution.

\section{Acknowledgements Competing interests}

The author declares that he has no financial or personal relationships that may have inappropriately influenced him in writing this article.

\section{References}

Bird, E., \& Welford, G. (1995). The effect of language on the performance of secondlanguage students in science examinations. International Journal of Science Education, 17(3), 389-397. https://doi.org/10.1080/0950069950170309

Bohlmann, C., \& Pretorius, E. (2008). Relationships between mathematics and literacy: Exploring some underlying factors. Pythagoras, 67, 42-55. https://doi. org/10.4102/pythagoras.v0i67.73

Caldas, S.J., \& Bankston, C. (2004). Effect of school population socioeconomic status on individual academic achievement. The Journal of Educational Research, 90(5), 269-277. https://doi.org/10.1080/00220671.1997.10544583

Chiu, M.M. (2007). Families, economies, cultures, and science achievement in 41 countries: Country, school, and student level analyses. Journal of Family Psychology, 21(3), 510-519. https://doi.org/10.1037/0893-3200.21.3.510

Coleman, J., Campbell, E., Hobson, C.J., McPartland, J., Mood A.M., \& Weinfeld, F.D. (1966). Equality of educational opportunity. Washington, DC: U.S. Government Printing Office. 
Feast, V. (2002). The impact of IELTS scores on performance at university. International Education Journal, 3(4), 70-85. Available from https://ehlt.flinders.edu.au/ education/iej/articles/v3n4/feast/paper.pdf

Howie, S.J. (2003). Language and other background factors affecting secondary pupil's performance in mathematics in South Africa. African Journal of Research in Science, Mathematics and Technology Education, 7, 1-20. Available from http:// hdl.handle.net/10520/EJC92785

Johnstone, A., \& Selepeng, D. (2001). A language problem revisited. Chemistry Education: Research and Practice in Europe, 2(1), 19-29. Available from http:// www.chem.uoi.gr/cerp/2001_February/pdf/05Johnstone.pdf

Murray, M. (2016). Does poor quality schooling and/or teacher quality hurt Black South African students enrolling for a degree at the University of KwaZulu-Natal? PLoS One, 11(4), 1-11. https://doi.org/10.1371/journal.pone.0153091

Naylor, R., \& Smith, J. (2005). Schooling effects on subsequent university performance: Evidence for the UK university population. Economics of Education Review, 24(5), 549-562. https://doi.org/10.1016/j.econedurev.2004.07.016
Spaull, N. (2011). Primary school performance in Botswana, Mozambique, Namibia and South Africa. SACMEQ Working Paper. Available from http://www.sacmeq.org/ sites/default/files/sacmeq/publications/08_comparison_final_18oct2011.pdf

Thiele, T., Singleton, A., Pope, D., \& Stanistreet, D. (2016). Predicting students' academic performance based on school and socio-demographic characteristics. Studies in Higher Education, 41(8), 1424-1446. https://doi.org/10.1080/03075079.2014.974528

Tomul, E., \& Savasci, H.S. (2012). Socioeconomic determinants of academic achievement. Educational Assessment, Evaluation and Accountability, 24(3), 175-187. https://doi.org/10.1007/s11092-012-9149-3

Van der Berg, S. (2008). How effective are poor schools? Poverty and educational outcomes in South Africa. Studies in Educational Evaluation, 34(3), 145-154. https://doi.org/10.1016/j.stueduc.2008.07.005

Van Dyk, T., Zybrands, H., Cillie, K., \& Coetzee, M. (2009). On being reflective practitioners: The evaluation of a writing module for first-year students in the health sciences. Southern African Linguistics and Applied Language Studies, 27(3), 333-344. https://doi.org/10.2989/SALALS.2009.27.3.10.944 